\title{
Aspek Kualitas Bakteriologis Depot Air Minum Isi Ulang (DAMIU) di Kabupaten Bandung Barat
}

\author{
Ari Khoeriyah, Anies \\ Program Magister Ilmu Lingkungan, Universitas Diponegoro
}

\begin{abstract}
Abstrak
Kebutuhan manusia akan air minum semakin bertambah seiring dengan bertambahnya jumlah penduduk, sedangkan kuantitas dan kualitas air minum semakin berkurang sehingga masyarakat mencari alternatif untuk mendapatkan air minum, salah satunya mengonsumsi air minum siap pakai dari Depot Air Minum Isi Ulang (DAMIU). Namun, tidak semua DAMIU terjamin kualitasnya. Penelitian bertujuan menganalisis keberadaan bakteri Coliform pada DAMIU di wilayah kerja Puskesmas Cipendeuy dan Padalarang Kabupaten Bandung periode Juni 2013. Pengumpulan data dilakukan pada 8 DAMIU dengan observasi dan uji laboratorium untuk mengetahui keberadaan bakteri Coliform dalam air DAMIU. Hasil pemeriksaan kadar Coliform pada beberapa sumber air baku, diketahui bahwa seluruh sumber air baku (100\%) memenuhi syarat walaupun ada 2 sumber air baku yang mengandung Coliform, tetapi dengan keadaan yang masih memenuhi baku mutu. Sementara itu, pemeriksaan air minum yang berasal dari 8 DAMIU, ternyata air minum yang berasal dari 6 DAMIU tidak memenuhi persyaratan (5 DAMIU mengandung Coliform sebesar 3 MPN/100 dan 1 DAMIU sebesar 4 MPN/100 mL), sedangkan air minum yang berasal dari 2 DAMIU lainnya memenuhi syarat. [MKB. 2015;47(3):137-43]
\end{abstract}

Kata kunci: Coliform, Depot Air Minum Isi Ulang (DAMIU), sumber air baku

\section{Aspect of Bacteriological Quality in DWRD as a Refill Drinking Water Station in the District of West Bandung}

\begin{abstract}
The human need for water is increasing with population growth.Meanwhile the quantity and quality of drinking water are decreasing that people look for alternatives for drinking water source. One of the alternatives is readyto-drink water from the Drinking Water Refill Depot (DWRD). However, not all of DWRDs provide good quality drinking water. This study aims to analyze the existence of Coliform bacteria in the drinking water provided by DWRDs. Data were collected from 8 DWRDs to reveal the DWRDs sanitation through observation and laboratory testings were performed to determine the presence of Coliform bacteria in the drinking water produced by DWRDs. Based on the examination on the Coliform level on several raw water sources, the raw water was considered qualified (100\%). However, 2 raw water sources contained Coliform, even though they were still considered meeting the requirements of quality standard. Testing was also conducted on the drinking water produced by 8 DWRDs. It was revealed that 6 DWRDs did not qualify (drinking water from 5 DWRDs contained 3 MPN/100 mL of Coliform and drinking water from 1 DWRDs contained 4 MPN/100 mL of Coliform), while 2 other DWRDs were qualified for providing drinking water. [MKB. 2015;47(3):137-43]
\end{abstract}

Key words: Coliform, Drinking Water Refill Depot (DWRD), raw water

Korespondensi: Ari Khoeriyah, SKM Magister Ilmu Lingkungan Universitas Diponegoro Jl. Imam Barjo SH No. 5 Semarang, Jawa Tengah, mobile 085227527987, e-mail: ari.khoeriyah@gmail.com 


\section{Pendahuluan}

Air merupakan kebutuhan utama bagi kehidupan. Kebutuhan akan air di suatu daerah akan selalu mengalami kecenderungan naik seiring dengan pertambahan penduduk, sedangkan air sendiri berkurang dari segi kualitas, kuantitas, dan juga kontinuitas. Sebanyak 75\% tubuh manusia terdiri atas air. Manusia membutuhkan air terutama untuk minum. Sementara itu, ketersediaan air terutama air tawar di dunia hanya sekitar 3\% dan 97\% lainnya merupakan air laut. Air yang dapat digunakan oleh manusia untuk keperluan sehari-hari hanya sekitar $0,3 \%{ }^{1}$

Sumber air baku dapat diambil dari mata air, Perusahaan Daerah Air Minum (PDAM), sumur bor, sumur gali, dan sumber lainnya yang telah direkomendasikan oleh Dinas Kesehatan Kabupaten atau Kota. Pada beberapa dekade terakhir ini, ketersediaan air di beberapa tempat mulai berkurang akibat kerusakan lingkungan dan anomali iklim secara global. Penurunan ketersediaan air baku untuk air minum salah satunya disebabkan oleh daya dukung lingkungan yang menurun pula. Hal ini ditunjukkan dengan semakin banyaknya daerah aliran sungai atau DAS yang kondisinya semakin memburuk sehingga tidak dapat menyimpan air dengan baik. Beberapa hal yang menyebabkan masalah ini, yaitu pesatnya pertumbuhan industri dan pemukiman penduduk yang mengakibatkan permintaan air tanah menjadi sangat meningkat. Akibatnya, kualitas air baku yang akan diolah menjadi air minum menjadi terpengaruh. ${ }^{2}$

Kebutuhan masyarakat akan tersedianya sarana air bersih (SAB) belum sepenuhnya terpenuhi. Oleh karena itu, masyarakat mencari berbagai alternatif untuk mendapatkan air salah satunya dengan mengonsumsi air minum siap pakai. Kecenderungan masyarakat untuk mengonsumsi air minum siap pakai seperti yang berasal dari Depot Air Minum Isi Ulang (DAMIU) sangat besar, selain karena mudah didapat juga harganya yang relatif terjangkau oleh sebagian besar masyarakat. Keadaaan ini ditunjukkan dengan pesatnya perkembangan jumLah DAMIU di Kabupaten Bandung Barat. Pada tahun 2008 tercatat 22 DAMIU dan tahun 2011 tercatat 155 DAMIU yang tersebar di 15 Kecamatan Kabupaten Bandung Barat. ${ }^{3}$ Hal ini menunjukkan peningkatan sebesar 133 DAMIU $(85,81 \%)$ dalam kurun waktu tiga tahun (dari tahun 2008 sampai dengan tahun 2011). DAMIU tersebut sebagian besar menggunakan PDAM sebagai sumber air bakunya, yaitu sebesar $80 \%$ dan $20 \%$ sisanya menggunakan air tanah.
Higiene sanitasi DAMIU yang tidak sesuai dengan ketentuan atau peraturan yang berlaku dapat mengakibatkan kualitas air minum yang dihasilkan tidak memenuhi standar kualitas air minum yang ditentukan karena apabila kualitas air minum tidak memenuhi syarat khususnya kualitas bakteriologis yang akan menimbulkan gangguan kesehatan. Gangguan kesehatan dapat menyebabkan penyakit seperti diare, kolera, tifoid, hepatitis, disentri, dan gastroenteritis. Kasus diare ini menempati urutan keempat dengan jumlah 30.839 kasus. JumLah kasus di wilayah kerja Puskesmas Cipeundeuy sebanyak 2.466 kasus dan di wilayah kerja Puskesmas Padalarang sebanyak 1.530 kasus. $^{3}$ Sementara itu, berdasarkan pemeriksaan DAMIU yang dilakukan oleh Dinas Kesehatan Kabupaten Bandung Barat pada Tahun 2012 diketahui bahwa sebanyak 34,667\% DAMIU (26 DAMIU dari 75 DAMIU) tidak memenuhi syarat karena masih mengandung bakteri Coliform. ${ }^{3}$

Penelitian ini dilakukan untuk mengetahui kualitas air minum isi ulang yang diproduksi Depot Air Minum Isi Ulang di wilayah kerja Puskesmas Cipeundeuy dan juga Padalarang berdasarkan persyaratan bakteriologis (jumLah Coliform) yang ditetapkan oleh Peraturan Menteri Kesehatan Republik Indonesia Nomor 492/ MENKES/PER/IV/2010 tentang persyaratan kualitas air minum dan mengetahui sumber air baku di depot air minum isi ulang tersebut. ${ }^{4}$

\section{Metode}

Penelitian dilakukan pada DAMIU di wilayah kerja Puskesmas Cipeundeuy dan Padalarang Kabupaten Bandung Barat pada periode Juni 2013. Penelitianini menggunakan jenis penelitian survei analitik. Pengambilan sampel air baku, sampel DAMIU, dan sampel responden dilakukan secara purposive sampling. Teknik ini digunakan berdasarkan atas pertimbangan tertentu yang dibuat oleh peneliti berdasarkan kriteria atau ciri populasi yang sudah diketahui sebelumnya. Pengambilan sampel air, wawancara, dan juga observasi dilakukan pada 3 DAMIU dan 2 sumber air baku di wilayah kerja Puskesmas Cipeundeuy dan 5 DAMIU serta 1 sumber air baku di wilayah kerja Puskesmas Padalarang. Sampel air baku dan air minum yang sudah diolah selanjutnya dianalisis di Laboratorium yang ditunjuk dan sudah rutin melakukan pemeriksaan air setiap tahun sebanyak satu kali, yaitu PDAM Kota Bandung. Wawancara ditujukan kepada pemilik DAMIU dan karyawan/petugas yang bekerja di 
DAMIU tersebut.

Pengukuran kualitas bakteriologis air baku DAMIU dilakukan berdasarkan observasi dan uji laboratorium bakteriologis keberadaan Coliform dengan metode most probable number (MPN) dengan standar PERMENKES nomor: 416/ MENKES/PER/IX/1990 tentang syarat-syarat dan pengawasan kualitas air yang menyatakan bahwa kadar maksimum yang diperbolehkan untuk total Coliform (MPN) air baku dalam air bukan perpipaan adalah $50 \mathrm{MPN} / 100 \mathrm{~mL}$, dan air perpipaan $10 \mathrm{MPN} / 100 \mathrm{~mL}$ sehingga bila kualitas bakteriologi air baku bukan perpipaan lebih dari 50 MPN/100 mL dan air baku perpipaan kualitas bakteriologi lebih dari 10 MPN/100 mL berarti air baku tersebut tidak memenuhi syarat (TMS). Jika air baku bukan perpipaan $\leq 50 \mathrm{MPN} / 100 \mathrm{~mL}$ dan air perpipaan $\leq 10 \mathrm{MPN} / 100 \mathrm{~mL}$ berarti air baku tersebut memenuhi syarat (MS). ${ }^{5}$ Bakteri Coliform merupakan jasad indikator di dalam substrat air, bahan makanan, saluran pencernaan manusia dan sebagainya untuk kehadiran jasad berbahaya/patogen. Apabila di dalam makanan tersebut terdapat Coliform maka makanan atau minuman tersebut secara mikrobiologis tercemar oleh tinja. Coliform dapat bertahan hidup di air tanah dangkal selama lebih dari 2 bulan. ${ }^{6}$

Pengukuran kualitas bakteriologis air minum DAMIU dilakukan berdasarkan observasi dan uji laboratorium bakteriologis keberadaan Coliform dengan metode most probable number (MPN) dengan standar Peraturan Menteri Kesehatan Republik Indonesia Nomor: 492/MENKES/ PER/IV/2010 tentang persyaratan kualitas air minum yang menyatakan bahwa di dalam 100 $\mathrm{mL}$ sampel air minum yang diperiksa tidak boleh mengandung Coliform, jadi harus nol/100 mL air sehingga bila kualitas bakteriologi air minum $\leq 0 \mathrm{MPN} / 100 \mathrm{~mL}$ berarti air minum tersebut memenuhi syarat (MS). Apabila air minum $>0$ MPN/100 mL berarti air minum tersebut tidak memenuhi syarat (TMS). ${ }^{4}$

\section{Hasil}

Kabupaten Bandung Barat merupakan salah satu kabupaten di Provinsi Jawa Barat dengan luas wilayah sekitar $130.577,40$ Ha dan terbagi menjadi 15 kecamatan serta 31 puskesmas. Lokasi penelitian ini difokuskan pada wilayah kerja Puskesmas Cipeundeuy dan Padalarang. Puskesmas Cipeundeuy merupakan salah satu puskesmas dengan jumLah kasus diare yang cukup tinggi, yaitu sebanyak 2.466 kasus dan kasus diare di Puskesmas Padalarang yaitu sebanyak 4.530 kasus. ${ }^{3}$ Asal sumber air baku DAMIU di Wilayah Kerja Puskesmas Cipeundeuy dan Padalarang Kabupaten Bandung Barat tahun 2013 dapat dilihat pada Tabel 1.

Tabel 1 menunjukkan bahwa asal sumber air baku yang digunakan di Depot Air Minum Isi Ulang (DAMIU) berasal dari mata air sebanyak 5 depot, dari PDAM sebanyak 2 depot, dan dari air sumur gali sebanyak 1 depot.

Kualitas bakteriologis sumber air baku pada 8 DAMIU di wilayah kerja Puskesmas Cipeundeuy dan Padalarang Kabupaten Bandung Barat tahun 2013 berdasarkan uji laboratorium dapat dilihat pada Tabel 2. Tabel 2 menunjukkan bahwa hasil uji laboratorium, semua sumber air baku di wilayah kerja Puskesmas Cipeundeuy dinyatakan Memenuhi Syarat (MS) walaupun terdapat 1 sumber air baku yang mengandung Coliform, tetapi masih memenuhi syarat sesuai Peraturan Menteri Kesehatan No. 416/Menkes/Per/ IX/1990 kadar maksimum yang diperbolehkan adalah $50 \mathrm{MPN} / 100 \mathrm{~mL}$ sampel..$^{7}$ Kandungan Coliform dari sumber air baku di wilayah kerja ini sebesar 28 MPN/100 mL. Sementara itu, sumber air baku DAMIU di wilayah kerja Puskesmas Padalarang mengandung Coliform sebesar 11 MPN/100 mL.

Kualitas bakteriologis air minum isi ulang di wilayah Puskesmas Cipeundeuy dan Padalarang tahun 2013 berdasarkan uji laboratorium dapat dilihat pada Tabel 3. Berdasarkan Tabel 3 untuk wilayah kerja Puskesmas Cipeundeuy terdapat 1 DAMIU yang mengandung Coliform sebanyak $4 \mathrm{MPN} / 100 \mathrm{~mL}$. Air baku yang digunakan oleh depot tersebut adalah dari PDAM. Hal ini berarti ada 1 DAMIU yang tidak memenuhi syarat (TMS) dan 2 lainnya memenuhi syarat (MS). Lain halnya dengan DAMIU di wilayah kerja Puskesmas Padalarang, ternyata semua DAMIU yang telah diteliti yaitu 5 DAMIU mengandung Coliform. Kandungan Coliform pada DAMIU di wilayah

\section{Tabel 1 Asal Sumber Air Baku DAMIU di Wilayah Kerja Puskesmas Cipeundeuy dan Padalarang}

\begin{tabular}{lc}
\hline \multicolumn{1}{c}{ Asal Sumber Air Baku } & $\begin{array}{c}\text { Jumlah } \\
\mathbf{n}\end{array}$ \\
\hline Mata air & 5 \\
PDAM & 2 \\
Air sumur gali & 1 \\
Total & 8 \\
\hline
\end{tabular}

Sumber: Data Primer (2013) 
Tabel 2 Kualitas Bakteriologis Sumber Air Baku di Wilayah Kerja Puskesmas Cipeundeuy dan Padalarang Tahun 2013

\begin{tabular}{lllcccc}
\hline $\begin{array}{c}\text { Wilayah Kerja } \\
\text { Puskesmas }\end{array}$ & $\begin{array}{c}\text { Nama } \\
\text { DAMIU }\end{array}$ & $\begin{array}{c}\text { Nama } \\
\text { Sumber Air } \\
\text { Baku }\end{array}$ & $\begin{array}{c}\text { Baku } \\
\text { Mutu }\end{array}$ & $\begin{array}{c}\text { Hasil } \\
\text { Pengujian }\end{array}$ & Metode Acuan & Keterangan \\
\hline \multirow{2}{*}{ Cipendeuy } & DAMIU 1 & PDAM & 50 & 28 & SM 9221 B ** & MS \\
& DAMIU 2 & PDAM & 50 & 0 & SM 9221 B ** & MS \\
& DAMIU 3 & Air Sumur & 50 & 0 & SM 9221 B ** & MS \\
& DAMIU 4 & Mata Air & 50 & 11 & SM 9221 B ** & MS \\
Padalarang & DAMIU 5 & Mata Air & 50 & 11 & SM 9221 B ** & MS \\
& DAMIU 6 & Mata Air & 50 & 11 & SM 9221 B ** & MS \\
& DAMIU 7 & Mata Air & 50 & 11 & SM 9221 B ** & MS \\
& DAMIU 8 & Mata Air & 50 & 11 & SM 9221 B ** & MS \\
\hline
\end{tabular}

Sumber: Data Primer (2013)

Keterangan: MS: memenuhi syarat

kerja Puskesmas Padalarang yaitu 3 MPN/100 mL sebanyak 4 DAMIU dan kandungan terendah yaitu 6 MPN/100 mL pada 1 DAMIU. Air baku yang digunakan oleh depot tersebut adalah dari mata air. Hal ini berarti semua (5 DAMIU) Tidak Memenuhi Syarat (TMS).

\section{Pembahasan}

Sumber air baku yang mengandung Coliform sebanyak 28 MPN/100 mL berasal dari PDAM, sedangkan sumber air baku yang digunakan oleh kelima depot yang mengandung Coliform sebanyak 11 MPN/100 mL adalah sama, yaitu dari mata air. Sumber air baku tersebut masih memenuhi syarat (MS), walaupun terdapat kandungan Coliform. Mata air adalah salah satu sumber air bersih yang baik jika dipergunakan sebagai air baku. Akan tetapi, setelah dilakukan uji laboratorium ternyata masih terdeteksi bakteri Coliform. Ke ini dapat terjadi karena lokasi mata air tersebut berada di daerah terbuka sehingga memungkinkan terkontaminasi oleh lingkungan sekitar. Observasi terhadap mata air yang digunakan sebagai sumber air baku di wilayah kerja Puskesmas Padalarang diketahui bahwa di atas daerah mata air terdapat suatu pemukiman warga asli di daerah tersebut. Permukiman tersebut mampu mengakibatkan pencemaran air tanah di bawahnya. Pencemaran ini dapat berasal dari buangan air rumah tangga, air cucian kamar mandi, buangan tinja atau

Tabel 3 Kualitas Bakteriologis Air Minum Isi Ulang di Wilayah Kerja Puskesmas Cipeundeuy dan Padalarang Tahun 2013

\begin{tabular}{ccccll}
\hline $\begin{array}{c}\text { Wilayah Kerja } \\
\text { Puskesmas }\end{array}$ & Nama DAMIU & Baku Mutu & $\begin{array}{c}\text { Hasil } \\
\text { Pengujian }\end{array}$ & Metode Acuan & Keterangan \\
\hline \multirow{4}{*}{ Cipendeuy } & DAMIU 1 & 0 & $4^{\wedge}$ & SM 9221 B ** & TMS \\
& DAMIU 2 & 0 & 0 & SM 9221 B ** & MS \\
& DAMIU 3 & 0 & 0 & SM 9221 B ** & MS \\
& DAMIU 4 & 0 & $3^{\wedge}$ & SM 9221 B ** & TMS \\
\multirow{5}{*}{ Padalarang } & DAMIU 5 & 0 & $3^{\wedge}$ & SM 9221 B ** & TMS \\
& DAMIU 6 & 0 & $3^{\wedge}$ & SM 9221 B ** & TMS \\
& DAMIU 7 & 0 & $3^{\wedge}$ & SM 9221 B ** & TMS \\
& DAMIU 8 & 0 & $6^{\wedge}$ & SM 9221 B ** & TMS \\
\hline
\end{tabular}

Sumber: Data Primer (2013)

Keterangan: MS: memenuhi syarat; TMS: tidak memenuhi syarat 
rembesan dari septic tank, maupun buangan sampah. Berbagai aktivitas masyarakat di permukiman berkontribusi terhadap kualitas air tanah. Kontaminan utama dari air tanah akibat permukiman yaitu terdapat senyawa nitrat, nitrit, fosfat, organik, dan mikrobiologis. ${ }^{7}$ Kemungkinan lainnya adalah penyedia air baku tersebut kurang memperhatikan kebersihan dan juga masa pakai selang yang digunakan untuk memasukkan air ke dalam suatu tangki, misalnya bocor, usang, berlumut, kotor, serta jarang atau bahkan tidak pernah dibersihkan. Steyer dkk. ${ }^{8}$ menyatakan dari 152 sampel air yang diteliti terdiri atas air tanah dari sumur responden (72 sampel), 17 sampel dari penyediaan publik, dan 63 sampel dari permukaan air sungai, menunjukkan persentase yang relatif tinggi terhadap pencemaran air tanah di Slovenia dan air tersebut jika digunakan untuk air minum maka memungkinkan tercemar oleh infeksi virus.

Kandungan Coliform pada berbagai sumber air baku berbeda antara sumber air baku yang satu dan yang lainnya. ${ }^{9}$ Sumber air baku yang berasal dari PDAM memiliki kandungan Coliform lebih tinggi daripada sumber air baku yang berasal dari air sumur maupun mata air. Hal ini sejalan dengan penelitian di Kham Yunis bahwa persentase kontaminan total dan fekal Coliform dalam air jaringan (PDAM) lebih tinggi daripada air sumur. ${ }^{10}$

Air baku yang bersumber dari mata air memiliki kualitas yang baik dibanding dengan air baku yang bersumber dari PDAM dan sumur. Hal ini disebabkan karena mata air adalah air tanah yang keluar dengan sendirinya ke permukaan tanah. Mata air yang berasal dari tanah dalam, hampir tidak terpengaruh oleh musim dan juga kualitasnya lebih baik daripada air dangkal karena penyaringannya lebih sempurna dan bebas dari bakteri. ${ }^{10}$ Terdapat Coliform dalam air baku mengindikasikan bahwa air tersebut telah terkontaminasi tinja manusia/hewan berdarah panas/kotoran lain. Coliform dapat bertahan hidup dalam air tanah dangkal selama lebih dari 2 bulan. ${ }^{6}$ Mata air yang belum memenuhi persyaratan bakteriologis maka harus dilakukan suatu upaya misalnya dengan mendesinfeksi atau memasaknya terlebih dahulu sebelum diminum. Salah satu metode desinfeksi yang secara luas diterapkan di Indonesia adalah dengan ozon. Ozon merupakan desinfektan yang sangat reaktif dalam menginaktifasi mikroorganisme. Efektivitas ozonisasi mata air dipengaruhi juga oleh suhu, pH, kekeruhan, TOC, alkalinitas, besi terlarut, jumLah bakteri Coliform dan E. coli. ${ }^{11}$
Air baku yang berasal dari air sumur di wilayah kerja Puskesmas Cipeundeuy tidak mengandung Coliform, kemungkinan disebabkan letak sumur jauh dari septic tank ataupun dari tempattempat yang memungkinkan kontaminasi antara lain tempat yang tergenang air, kandang ternak, sungai yang tercemar, berdekatan dengan industri dan juga tempat pembuangan sampah/ kotoran. Hal ini dapat terjadi karena wilayahnya yang masih termasuk pedesaan, dan relatif luas sehingga memungkinkan bagi pemilik depot untuk membuat sumur dengan jarak yang jauh dari sumber pencemar. Sementara itu, penelitian yang dilakukan di India menyatakan bahwa semua sumur yang diteliti mengandung bakteri Coliform. Air sumur yang berada di sekitar kawasan industri akan berbahaya bagi kesehatan penduduk setempat apabila dikonsumsi. ${ }^{12}$

Sumber air minum yang tercemar Coliform kemungkinan disebabkan oleh rembesan dari septic tank, sistem pembuangan sampah yang kurang dan limbah padat. ${ }^{13,14}$ Aktivitas yang memiliki potensi meningkatkan kandungan total Coliform dan E. coli, yaitu dari kotoran ternak, laundry, dan juga rembesan jamban. ${ }^{15}$ Kualitas bakteriologis air sumur gali dipengaruhi oleh jarak jamban terhadap sumur gali tersebut. ${ }^{16}$

Menurut Keputusan Menteri Perindustrian dan Perdagangan Republik Indonesia Nomor 651/MPP/Kep/10/2004 tentang Persyaratan Teknis Depot Air Minum dan Perdagangannya Pasal 3 ayat 3 menyatakan bahwa pengujian terhadap mutu air baku dilakukan minimal 1 kali dalam 3 bulan untuk analisis Coliform dan 2 kali dalam 1 tahun untuk analisis kimia dan fisika secara lengkap. ${ }^{17}$

Air minum yang dikonsumsi oleh masyarakat tidak semuanya terbebas dari Coliform. Seperti yang pernah dilakukan penelitian di Brazil juga menyatakan bahwa 76,6\% sampel air mineral sebanyak 20-L yang merupakan kumpulan dari air dispenser terkontaminasi oleh setidaknya 1 coliform atau bakteri indikator atau setidaknya 1 bakteri patogen.$^{18}$ Coliform merupakan bakteri yang hidup di dalam usus manusia, jadi apabila air minum mengandung Coliform merupakan indikator bahwa air minum tersebut telah tercemar oleh tinja. Keadaan ini mungkin dapat diakibatkan oleh kesehatan penjamah yang kurang baik, kualitas fisik DAMIU, sumber air baku yang kurang baik ataupun higiene sanitasi serta fasilitas sanitasi yang kurang memadai, semuanya saling berkaitan dan tidak dapat dipisahkan. Coliform bukan merupakan bakteri penyebab penyakit, tetapi dapat dipergunakan sebagai salah satu indikator terdapat bakteri 
patogen yang dapat mengakibatkan berbagai macam penyakit. Hasil penelitian di Charsadda, Pakistan menyatakan bahwa terdapat penduduk yang menderita penyakit seperti gastroenteritis, kolera, disentri, diare, dan hepatitis karena mengonsumsi air yang tercemar Coliform..$^{13}$ Peningkatan kualitas air berpengaruh positif dan signifikan terhadap efek kesehatan yaitu insiden penyakit diare pada orang dewasa menurun sebesar $11 \%{ }^{19}$

Simpulan, pemeriksaan Coliform pada sumber air baku diketahui seluruh sumber air baku memenuhi syarat walaupun ada 2 sumber air baku yang mengandung Coliform, tetapi dengan keadaan yang masih memenuhi baku mutu. Pemeriksaan air minum di 8 DAMIU terdapat 6 DAMIU yang mengandung Coliform, sebesar 3 MPN/100 mL untuk 5 DAMIU dan 4 MPN/100 mL untuk 1 DAMIU sehingga tidak memenuhi syarat, 2 DAMIU lainnya memenuhi syarat.

\section{Ucapan Terima Kasih}

Kepada Pusbindiklatren Bappenas yang telah memberikan dukungan dan beasiswa selama menjalankan studi dan penelitian ini. Bupati Bandung Barat yang telah memberikan izin tugas belajar untuk menempuh studi program pascasarjana.

\section{Daftar Pustaka}

1. Kementerian Kesehatan RI. Menjaga air minum anda tetap aman. Jakarta: Direktorat Jenderal Pengendalian Penyakit dan Penyehatan Lingkungan Kementerian Kesehatan RI; 2011.

2. Joko T. Unit air baku dalam sistem penyediaan air minum. Yogyakarta: Graha Ilmu; 2010.

3. Dinas Kesehatan Kabupaten Bandung Barat. Profil Dinas Kesehatan Kabupaten Bandung Barat Tahun. Bandung: Dinas Kesehatan Kabupaten Bandung Barat; 2011.

4. Kementerian Kesehatan RI. Peraturan Menteri Kesehatan Republik Indonesia Nomor 492/MENKES/PER/IV/2010 tentang persyaratan kualitas air minum. 2010.

5. Kementerian Kesehatan RI. Peraturan Menteri Kesehatan Republik Indonesia Nomor 416/MENKES/PER/IX/1990 tentang Syarat-syarat dan Pengawasan Kualitas Air. 1990.

6. McCarthy TC, Gumbricht T, Stewart RG, Brandt D, Hancox PJ, McCarthy J dkk.
Wastewater disposal at Safari Lodges in the Okavango Delta, Botswana. Water SA. 2004;30(1)121-8.

7. Love D, Zingoni E, Gandidzanwa P, Magadza C, Musiwa K. Impact on groundwater quality and water supply of the epworth semi-formal settlement, Zimbabwe. Dalam: Hranova R, penyunting. Diffuse pollution of water resources: principles and case studies in the Southern African Region. BALKEMAProceedings and Monographs in Engineering, Water and EarthScience. Botswana: University of Botswana, Gaborone; 2006. hlm. 153-73.

8. Steyer A, Torkar KG, Aguirre IG, Prijatelj MP. High prevalence of enteric viruses in untreated individual drinking water sources and surface water in slovenia. Inter J Hyg Environ Health. 2011;214(5):392-8.

9. Herawati T, Purwanto A, Setiyono A. Perbedaan jumlah coliform pada air minum isis ulang setelah pengolahan berdasarkan sumber air baku di Depot Air Minum Isi Ulang Kota Tasikmalaya tahun 2012. Jurnal Unsil [Online Jurnal] 2012 [diunduh 11 Oktober 2013]. Tersedia dari: http://journal. unsil.ac.id

10. Abu ASS, Yassin MM. Microbial contamination of drinking water distribution system ang its impact on human health in Khan Yunis Governorate, Gaza Strip: seven years of monitoring (2000-2006). Public Health. 2008;122:1275-83.

11. Sari NN, Sururi R, Pharmawati K. Efek perlakuan $\mathrm{pH}$ pada ozonisasi pada mata air. reka lingkungan Jurnal Institut Teknologi Nasional. 2013;1(1)1-12.

12. Shaji C, Nimi H, Bindu L. Water quality assesment of open wells in and around Chavara Industrial Area, Quilon, Kerala. J Environmen Biol. 2009;30(5):701-4.

13. Khan S, Shahnaz M, Jehan N, Rehman S, Shah MT, Din I. Drinking water quality and human health risk In Charsadda District, Pakistan. J Cleaner Production. In Press 2012;1-9.

14. Cabral J. Water microbiology, bacterial pathogens and water. Int J Environ Res Public Health. 2010;7(10):3557-703.

15. Gwimbi P. The microbial quality of drinking water in Manonyane Community: Maseru District (Lesotho). African Health Sci. 2011; 11(3):474-80.

16. Khomariyatika, Tattit, Pawenang ET. Faktor yang Berhubungan dengan kualitas bakteriologis air sumur gali. KEMAS. 2011;7(1)69-78. 
Ari Khoeriyah: Aspek Kualitas Bakteriologis Depot Air Minum Isi Ulang (DAMIU) di Kabupaten Bandung Barat

17. Kementerian Perindustrian dan Perdagangan RI. Keputusan Menteri Perindustrian dan Perdagangan Republik Indonesia Nomor 651/MPP/Kep/10/2004 tentang persyaratan teknis depot air minum dan perdagangannya; 2004.

18. Da Silva MEZ, Santana RG, Guilhermetti M, Filho IC, Endo EH, Nakamura TU, dkk.
Comparison of the bacteriologi quality of tap water and bottled mineral water. International J Hyg Environ Health. 2008; 211(5-6):504-9.

19. Zhang J. The impact of water quality on health: evidence from infrastructure program in Rural China. J Health Economics. 2012;31:122-34. 